Lurian Journal. 2020. Vol. 1, No. 2. P. 44-57.

D0l 10.15826/Lurian.2020.1.2.4

УДК 616.89

\title{
Space in Luria Neuropsychology: Ideas, Clinical Phenomenology, Research Methods
}

\author{
Elena Yu. Balashova \\ Moscow State University named after M. V. Lomonosov, \\ Department of Psychology, \\ Psychological Institute of the Russian Academy of Education, \\ Moscow, Russia
}

\section{Пространство в луриевской нейропсихологии: идеи, клиническая феноменология, методы исследования}

\author{
Елена Ю. Балашова \\ Московский государственный университет имени М. В. Ломоносова, \\ факультет психологии, \\ Психологический институт Российской академии образования, \\ Москва, Россия \\ Corresponding author.E-mail:elbalashova@yandex.ru
}

\begin{abstract}
The article discusses various aspects of research on spatial functions in Russian neuropsychology. According to the author, spatial functions are those mental processes whose main purpose is to obtain information about the spatial properties of objects and perform spatial actions and operations. The author analyzes some aspects of the neuropsychological approach to the perception and understanding of violations of the mental reflection of space. The article discusses some cultural and historical prerequisites for the emergence of a neuropsychological approach to the study of spatial functions. There are also data on references to spatial disorders in the works of the founders of clinical psychology in Russia S. S. Korsakov and V.M. Bekhterev. The author writes that A. R. Luria's interest in space arose even before the emergence of neuropsychology as an independent science. In the research on the mental development of children, conducted by him in the second half of the 20s of the last century together with L.S. Vygotsky, the attentive reader will find data on the development of various spatial representations. Long-term study of violations of spatial functions in local brain lesions allowed A.R. Luria, his colleagues and students not only to describe various symptoms of disturbances of spatial components of perception, memory, thinking, and
\end{abstract}


voluntary movements, but also to significantly clarify the idea of the complex brain organization of the so-called spatial factor. In addition, Luria neuropsychology was able to develop an original integrative model of the spatial organization of the human brain, in which various cerebral zones and structures work in concert to ensure the fulfillment of various mental and behavioral tasks. Analyzing the work of A. R. Luria, the author, along with undoubted achievements, notes some discrepancies and gaps in the study of spatial disorders. It is shown that in the fundamental monographs of A. R. Luria, violations of the spatial aspects of tactile and auditory perception and spatial memory were discussed very concisely. Ideas about the "vertical organization" of spatial functions, i. e. the contribution of not only cortical areas of the brain, but also subcortical structures to their implementation, also developed gradually. This statement is also true when it comes to a comparative analysis of violations of spatial functions in local lesions of the right and left hemispheres of the brain. A significant contribution to the development of the problem of functional asymmetry of the brain hemispheres in the processes of spatial analysis and synthesis was made not only by Moscow neuropsychologists, but also by their Leningrad colleagues - L. Ya. Balonov, V. L. Deglin, E. P. Kok, Ya. A. Meerson and others. After the death of A. R. Luria his followers (N. K. Korsakova, Yu. V. Mikadze, E. G. Simernitskaya) began to develop new areas of neuropsychological science - the neuropsychology of childhood and aging. The article discusses in detail the history of creation and current state of the complex of empirical methods used for neuropsychological diagnostics of spatial functions. Special attention is paid to the possibility of using the chronotope category in neuropsychological research.

Keywords: neuropsychology; spatial functions; diagnostics; brain dysfunctions; time

Аннотащия. В статье обсуждаются различные аспекты исследований пространственных функций в отечественной нейропсихологии. По мнению автора, пространственные функции - это те психические процессы, основной целью которых является получение информации о пространственных свойствах объектов и выполнение пространственных действий и операций. Автор анализирует некоторые аспекты нейропсихологического подхода к восприятию и пониманию нарушений психического отражения пространства. В статье обсуждаются культурно-исторические предпосылки возникновения нейропсихологического подхода к изучению пространственных функций. Также приводятся данные об упоминаниях пространственных расстройств в работах основоположников клинической психологии в России - С. С. Корсакова и В. М. Бехтерева. Автор напоминает о том, что А.Р. Лурия проявлял интерес к пространству еще до возникновения нейропсихологии как самостоятельной науки. В исследованиях психического развития детей, проводимых им во второй половине 20 -х гг. прошлого века совместно с Л. С. Выготским, уже содержатся данные о развитии различных пространственных представлений. Многолетнее изучение нарушений пространственных функций при локальных поражениях мозга позволило А. Р. Лурия, его коллегам и ученикам не только описать разнообразные симптомы нарушений пространственных компонентов восприятия, памяти, мышления, произвольных движений, но и существенно уточнить представления о сложной мозговой организации так называемого 
пространственного фактора. Кроме того, луриевской нейропсихологией разработана оригинальная интегративная модель пространственной организации человеческого мозга, ученые установили, что для обеспечения выполнения разнообразных психических и поведенческих задач в мозге согласованно действуют различные церебральные зоны и структуры. Анализируя работы А. Р. Лурия, автор, наряду с несомненными достижениями, отмечает некоторые диспропорции и лакуны в изучении пространственных расстройств. Показано, что в фундаментальных монографиях А.Р. Лурия весьма лаконично обсуждались нарушения пространственных аспектов тактильного и слухового восприятия, пространственной памяти. Лишь постепенно складывались представления о «вертикальной организации» пространственных функций, т. е. о вкладе не только корковых зон мозга, но и подкорковых структур в их реализацию. Так же постепенно происходило обращение к сравнительному анализу нарушений пространственных функций при локальных поражениях правого и левого полушарий мозга. Существенный вклад в разработку проблемы функциональной асимметрии полушарий мозга в процессе пространственного анализа и синтеза внесли не только московские нейропсихологи, но и их ленинградские коллеги - Л. Я. Балонов, В. Л. Деглин, Е. П. Кок, Я.А. Меерсон и др. Ученики А. Р. Лурия (Н. К. Корсакова, Ю. В. Микадзе, Э. Г. Симерницкая) уже после его смерти начали разработку новых направлений нейропсихологической науки - нейропсихологии детского возраста и старения. В этих исследованиях довольно существенное место занимает изучение возрастных особенностей пространственных функций. В статье подробно обсуждается история создания и актуальное состояние комплекса методик, которые используются для нейропсихологической диагностики пространственных функций. Спектр этих методик постоянно расширяется; создаются и апробируются новые методы изучения пространственной памяти, внимания и оптико-конструктивной деятельности. Наиболее интенсивно этот процесс разворачивается сегодня в нейропсихологии детского возраста. Особое внимание в статье уделяется возможности использования категории хронотопа в нейропсихологических исследованиях. Известно, что во многих гуманитарных и естественных науках уже несколько десятилетий применяется это понятие, постулирующее закономерную связь пространственных и временных характеристик разных явлений окружающего мира и человеческой личности. Применение категории хронотопа в нейропсихологии перспективно в двух отношениях. Во-первых, подобный методологический подход может раскрыть те мозговые зоны и структуры, которые реализуют восприятие и пространства, и времени. Фактически это означает уточнение представлений о мозговой организации двух важнейших нейропсихологических факторов: пространственного и временного. Во-вторых, категория хронотопа раскрывает новые ракурсы культурно-исторической нейропсихологии и может стать тонким инструментом анализа постоянно изменяющихся условий функционирования мозга и психики в социальной реальности.

Ключевые слова: нейропсихология; пространственные функиии; диагностика; мозговые дисфункиии; время 


\section{Introduction}

In this article, the author will try to highlight some aspects of the neuropsychological approach to the perception and interpretation of the vast phenomenology of "breakdowns" of the mental reflection of space, which has been attracting the attention of neuropsychologists for several decades. We will talk about violations (or changes) the so-called spatial functions are those mental processes that implement a multi-level and multi-stage analytical and synthetic processing of information about various spatial properties and features of the external world and your own body. These are mental functions aimed at obtaining information about the spatial properties of objects, at performing spatial transformations as their main goal. This is how we can talk about spatial memory, spatial organization of movements, and spatial perception.

\section{Space Before Neuropsychology}

Before turning to the field of neuropsychological research, I would like to briefly touch on the history of the issue (and quite a long history). This story suggests that the need to experience various changes in space has been inherent in man for thousands of years. In ancient times, it was realized in the myths, fairy tales, and fantasies of many peoples. Just imagine how many intriguing spatial transformations the reader can easily find in familiar fairy tales from childhood. For example, why such uncertainty in specifying the spatial coordinates of events occurring in fairy tales? They happen in a certain Kingdom, in a far-away state. The space seems to be marked, but with a peculiar "inaccuracy." One can only guess at the reasons for this inaccuracy, among which there is an attempt to protect the narrator from accusations of fiction, and the aesthetic impossibility of operating in a mythological-fairy-tale context with accurate units of distance measurement.

Another fact is that myths and legends repeatedly present hardly possible real transformations of space. In them, you can become a dwarf or a giant; turn into a Laurel tree, a bird, a snake, a spider, a frog, an ugly giant Troll or a celestial constellation; even become invisible, while maintaining the ability to actively and successfully influence events. These spatial and temporal transformations have different meanings and different goals; they are a demonstration of divine power, a punishment, a reward, a way to escape from trouble. Note that the fantasy plan for the development and interiorization of space that arose many millennia ago still exists today in numerous literary works, films and computer games, where space, solving artistic and commercial problems, becomes the object of innumerable and striking manipulations. Such a level of ideas about space in the consciousness of modern man quite successfully coexists with scientific ideas about this category.

As for clinical psychology, which has a history of almost a century and a half, it has a special relationship with space. From the first years of its existence, this field of science is faced with various psychopathological phenomena related to space. For example, in the works of S. S. Korsakov, one of the founders of clinical psychology in Russia, devoted 
to various mental disorders in the so-called alcoholic polyneuritis, along with memory disorders, there is a mention of difficulties in orientation in space and time inherent in this disease (Korsakov, 1954). S. S. Korsakov suggests that these difficulties may be due to memory disorders. In the works of V.M. Bekhterev, dating back to the beginning of the last century, there are descriptions of violations of the «body schema» in mental disorders (Bekhterev, 1954). Let's emphasize an interesting fact: already in the clinical and psychological research of the XIX century, space seems to have a double meaning. On the one hand, scientists are interested in changes in the perception of space that occur in mental disorders (and subsequently in other mental processes that include spatial components). On the other hand, space acts as a factor, a cause, on the action of which, perhaps, depends the nature and qualitative features of mental disorders. Referring to the works of S.S. Korsakov already mentioned above will easily allow us to find evidence for this thesis. For example, analyzing the pathological mechanisms of memory disorders, S. S. Korsakov attracts explanations that have a spatial subtext. In his opinion, the dissociation between the violation of remembering current events and the preservation of memory for the past is due to the fact that images of long-ago events have managed to form a wide system of connections with the entire mental life of the subject (Korsakov, 1954).

\section{Luria's Neuropsychology in Search of Space: Achievements and Problems}

Of course, among all the areas of Russian clinical psychology, it is in neuropsychology that the interest in the study of space is most clearly expressed. Long-term study of local brain lesions allowed A. R. Luria, his colleagues and students not only to describe various symptoms of violations of spatial components of perception, memory, thinking, and voluntary movements, but also to significantly clarify the idea of the complex brain organization of the so-called spatial factor (Korchajinskaya \& Popova, 1977; Luria, 1962, 1973; etc.). Luria's neuropsychology has developed an original integrative model of the spatial organization of the human brain, in which different cerebral zones and structures act in concert to ensure the fulfillment of various mental and behavioral tasks. We will reveal in more detail some important aspects of these studies.

First of all, it should be noted that A. R. Luria's interest in space appeared, apparently, long before the emergence of neuropsychology as an independent science. Even during his collaboration With L. S. Vygotsky, his attention was drawn to the facts concerning the heterochronous folding of spatial representations and skills in cultural and ontogeny. In the early 30s of the last century, a book written by him in collaboration with L. S. Vygotsky Etudes on the History of Behavior, which, in particular, describes the authors' most interesting research on the development of ideas about form, number, and space coordinates in childhood (Vygotsky \& Luria, 1993). Note that these studies were not neuropsychological. A few decades later (after the death of Alexander Romanovich), his followers - E. G. Simernitskaya, Yu. V. Mikadze and others will have to study the features 
of the brain organization of spatial functions in childhood (Glozman, 2019; Korsakova, Mikadze, \& Balashova, 2017; Mikadze, 2008; Simernitskaya, 1985).

It should also be said that the place of space in the scientific work of A. R. Luria is very significant, although we do not find in his literary heritage monographs or textbooks dedicated specifically to this psychological phenomenon. In the mid-40s of the last century, A. R. Luria published several articles that analyze violations of the understanding of number and counting operations in brain pathology (Chomskaya, 1992). In any monograph of the 1960s - 1970s. (Higher Cortical Functions in Man and Their Disturbances in Local Brain Lesions, The Basics of Neuropsychology, etc.) the reader will find chapters devoted to the syndrome analysis of violations of spatial aspects of visual perception, voluntary movements, memory, thinking, speech in brain lesions (Luria, 1962, 1973). Much attention is paid to spatial disorders and ways to overcome them in the case study Lost and Returned World (Luria, 1971). All these studies contain a detailed qualitative analysis of the symptoms of spatial disorders detected during neuropsychological research. Of course, not all mental functions were studied by A. R. Luria in the same detail. For example, describing in the monograph Higher Cortical Functions in Man and Their Disturbances in Local Brain Lesions syndromes of damage to the occipital and occipital-parietal parts of the brain, Alexander Romanovich describes in great detail the various manifestations of visual spatial agnosia, violations of orientation in space, constructive apractoagnosia. At the same time, violations of tactile perception of the form of objects, "skin reading", tactile attention are described by him very briefly; he refers in this small section to the works of other authors and directly says that "he does not have his own research on tactile syntheses" (Luria, 1962, p. 127). The spatial aspects of auditory perception are also practically not disclosed in the text of this book.

These facts reveal to us some features of the style of scientific work of A. R. Luria. The first feature is the author's excellent familiarity with the research of other scientists. His works necessarily contain numerous and detailed historical excursions that precede not only fundamental monographs, but also individual sections of these monographs. In these excursions, Luria focuses on the results of medical, physiological, and psychological research by Russian and foreign scientists. And this is not just a detailed, narrative and unbiased description of the numerous theories proposed by various scientists and the phenomena they observe. For him, the presentation of the "question's history" is not the main goal, but an important stage of thinking about the problem, a necessary prerequisite for moving on to the presentation of the results of his own experimental or neuropsychological research. These reflections often sound emotional notes; they often become a critical analysis of concepts, hypotheses, and clinical observations. Luria's view (biased in the good sense of the word) easily finds in the ideas of other authors theses that need experimental verification, correction, and understanding from other positions. Moreover, this view "is set" not only to debate; he finds joy in other people's works, ideas and facts that corresponds to the theory of systemic dynamic localization of mental functions, the syndromic analysis of violations or cultural-historical theory of the development of mentality. 
The second feature is a clear definition of the priority areas of their own research. For example, in the above-mentioned monograph Higher Cortical Functions in Man and Their Disturbances in Local Brain Lesions, A. R. Luria, based on the dominant role of the cerebral cortex in the cerebral maintenance of the psyche, practically does not include in the syndromes described by him manifestations of dysfunction of subcortical structures (Luria, 1962). Interestingly, this term is absent even in the subject index of the monograph. At the beginning of the 60 s, this position seems quite reasonable: while neuropsychology almost nothing is known about the role of various deep subcortical structures in mental processes. The reader is well aware that in the second half of the 60s there was a decisive revolution in this area. A. R. Luria, his graduate students and colleagues turn to intensive comprehensive research of memory disorders. Recall that in the previous period, they studied mainly memory disorders as mnestic activity (the so-called higher forms of memory) in lesions of the frontal lobes, arising as a result of a lack of motivation, arbitrary regulation, control, as a result of the inability to use memory-mediating techniques and strategies (Luria, 1962). And now, new research reveals a surprising fact. It turns out that the grossest memory disorders (amnesic syndrome) can be observed in lesions of the median structures of the brain. And they include not only the medio-basal cortex of the frontal and temporal lobes, but also deep subcortical formations (Kiyashchenko, 1973; Luria, 1973).

This significant event leads to the gradual formation of ideas that any mental function has a vertical organization, provided by the joint activity of the cortex and subcortical structures. Moreover, sometimes lesions of subcortical structures cause no less severe disorders than lesions of the cerebral cortex. As an example, we can mention such functions as dynamic praxis, gnosis of rhythms (evaluation and reproduction of rhythmic structures of varying complexity), and perception of time. Colleagues of A. R. Luria also come to the conclusion that in subcortical structures lesions severe disturbances of spatial functions can be observed, for example, manifestations of unilateral spatial agnosia (Korchajinskaya \& Popova, 1977).

The interest of neuropsychologists in subcortical structures has not weakened to this day: it concerns the functional specialization of various subcortical structures, their contribution to the "energy" provision of mental activity, in the work of memory, voluntary movements, attention, affective sphere, in the pathogenesis of neurological and mental diseases (Buklina, 2016; Balashova, 2016).

It should be emphasized that no less interesting studies of spatial functions unfolded during the Luria era not only in Russia, but also in foreign countries. These studies concerned spatial perception (in particular, the phenomenon of unilateral spatial neglect, memory, attention, orientation in space, spatial organization of movements). A. R. Luria and his colleagues often cited books and articles of foreign scientists in their works devoted to the mental reflection of space (Korchajinskaya \& Popova, 1977; Luria, 1962, 1973; and others). For example, in Higher Cortical Functions A. R. Luria mentions the research of J. de Ajuriaguerra, H. Head, H. Hecaen, K. Kleist, H.L. Teuber, O.L. Zangwill, and other modern authors. At the same time, it is important to understand that foreign stu- 
dies of space in most cases are based (both in the past and in the present) on a different methodological basis than the work of the Luria's school. The Lurian approach necessarily provides for a syndrome analysis of violations of the spatial factor. This means that the researcher analyzes the state of spatial components of various mental functions and finds common features in the symptoms of their disorders. Often such research is supplemented by special methods and tasks aimed at studying a particular spatial function. All the results obtained are necessarily compared with clinical data on the localization and other characteristics of brain damage.

In the research of foreign authors, we see a different approach. Most publications are based on the use of one (rarely - several) experimental methods, and the researcher studies how their performance is disrupted in various brain dysfunctions. Today, such studies often make comparisons with neuroimaging data. This approach allows you to see a lot of interesting facts. However, collecting these facts together, generalizing them, and describing the holistic syndrome of spatial disorders is quite a difficult task. Therefore, there are very limited number of such fundamental works.

\section{Space and Functional Asymmetry of the Brain}

Another example concerns the problem of functional asymmetry of the brain hemispheres. Interest in this problem (and, consequently, in the regularities of the right hemisphere activity) began to appear in the research of Russian neuropsychologists quite late in comparison with their foreign colleagues. This only happened in the late $60 \mathrm{~s}$ and the first half of the 70s. In the already mentioned monograph Higher Cortical Functions in Man and Their Disturbances in Local Brain Lesions, Luria devotes a relatively small text of about 4 pages to the so-called subdominant (right) hemisphere (Luria, 1962).

The text, by the way, is rich in information. It deeply analyzes the brain organization of speech function; arguments are put forward in favor of the priority role of the left hemisphere in speech processes. However, it he writes about the connection of certain aspects of speech activity (for example, "elementary functions of automated speech") with the right hemisphere of the brain (Luria, 1962, p. 76-77). A. R. Luria mentions various data from foreign authors in this text. These data concern assumptions about the dominance of the right hemisphere in the perception of music, in tactile gnosis.

But the role of the right hemisphere in the implementation of spatial aspects of mental processes is practically not discussed. He's writing:

It is easy to see that the lack of our knowledge about the degree of hemispheric dominance in different individuals with respect to different functions creates significant difficulties in the clinical study of patients with local brain lesions. Therefore, some important issues can only be solved in the first approximation... In this book, we deliberately leave all these problems out of our consideration, maintaining the confidence that with the accumulation of the necessary knowledge, their solution will be possible (Luria, 1962, p. 79). 
And this attitude is consistently implemented throughout the book: it deals mainly with the localization of mental functions. The problem of their lateralization is not specifically discussed, although the description of individual clinical cases necessarily contains data on the lateralization of the pathological process in the right or left hemisphere.

Ten years later, a new fundamental monograph by A. R. Luria The Basics of Neuropsychology (Luria, 1973) is published. And the setup is basically the same: only part of a small Chapter (about 6 pages) is dedicated to the right hemisphere. The volume of the book is 373 pages. But if you read carefully, you will notice that the list of cited foreign authors has significantly expanded. Moreover, there were mentions of new research on the right hemisphere by Russian neuropsychologists: E. S. Bein, L. G. Chlenov, E. P. Kok, V. I. Korchajinskaya, E. G. Simernitskaya and others. Facts directly related to spatial disorders also begin to "sound." Luria mentions violations of the "body schema," ignoring the left half of space, violations of orientation in real space, and "apraxia of dressing" (Luria, 1973, p. 225).

Thus, we can assume that one of the important personal qualities of A. R. Luria as a scientist was the ability to "build" a hierarchy of their scientific interests, to determine their main and secondary. Tasks that seemed to him not very important or relevant, he deliberately pushed into the future. Sometimes this future was very remote; it became not his personal future, but the future of his students or other scientists. Maybe it was a shift not only to another time, but also to another space - outside the sphere of the most significant personal scientific interests. Note that the followers of Alexander Romanovich managed to fill in many gaps in their knowledge of space.

Today, in the context of the neuropsychological approach, the processing of spatial information at the Gnostic, mnestic and semantic levels has been studied in depth. The complex of brain zones and systems involved in the implementation of spatial analysis and synthesis is clarified. According to scientists, the brain supply of the spatial factor is provided not only by the cortical zones of the posterior parts of the cerebral hemispheres, but also by various deep subcortical structures, interhemispheric commissures and premotor parts of the brain. The role of the right and left hemispheres of the brain in the perception of visual and auditory space, in visual constructive activity is studied in detail (Balonov \& Deglin, 1976; Bragina \& Dobrokhotova, 1988; Meerson, 1986). An extensive array of data on the features of spatial functions in normal and pathological aging was obtained (Balashova, 2015a, 2015b). Scientists are studying individual differences in brain organization of spatial functions and communication the success of spatial samples with the character profile of the lateral organization of the brain (Chomskaya, Efimova, Budyka, \& Enikolopova, 2011).

\section{Methods for Studying Spatial Functions}

Research on spatial functions in Luria's neuropsychology would not be possible without appropriate diagnostic techniques. An important part of the scientific heritage of A. R. Luria is an extensive set of diagnostic methods, which are used to study optical- 
spatial perception, constructive activity, spatial praxis, understanding of spatial and quasi-spatial patterns of speech, spatial components of mental operations (Luria, 1962). These techniques were mostly created by A. R. Luria. They are partly borrowed by Luria and his colleagues from other Russian and foreign authors (for example, some methods aimed at studying the spatial organization of movements, tactile perception, etc.). They are logically integrated into the methodology of the syndrome analysis of disorders of mental functions. The range of methods used by Russian neuropsychologists is constantly expanding; new methods for studying spatial memory, attention, and optical constructive activity are being created and tested. It seems that this process is most intensively unfolding today in the neuropsychology of childhood (Glozman, 2019). All these methods are aimed primarily at identifying broken or insufficiently formed links of spatial functions. Their complex application allows us to obtain results that complement and refine each other (Balashova \& Kovyazina, 2019).

For example, when studying the spatial factor in memory processes, such "cross" control can be expressed in the study of the features of memorizing not only visual-spatial stimuli, but also the possibilities of capturing the localization of individual subject images or word order when memorizing auditory-speech stimuli. Let's not forget about the classic Luria's method of drawing a geographical map, the use of which allows us to judge the possibility of updating the reserves of long-term spatial memory strengthened in individual experience of knowledge. The use of spatial neuropsychological methods allows us to evaluate not only the final result of activity, but also the neurodynamic, motivational, regulatory and operational components of the process of their implementation. In neuropsychological diagnostics of spatial functions, the analysis of the qualitative features of detected disorders is necessarily combined with a quantitative assessment of the severity of symptoms (Balashova \& Kovyazina, 2019). For example, when interpreting the results of determining time by a "silent" clock, more than five possible errors are identified (coordinate "mirror" errors, dysmetric errors, ignoring part of the dial, etc.). The type and frequency of errors made will depend on the assumptions of the neuropsychologist about the localization and lateralization of brain dysfunction, the degree of severity of spatial deficits. At the same time, we never forget that any symptom acquires its true meaning only in the syndrome of violations of higher mental functions. Therefore, the correct interpretation of spatial symptoms and the determination of their "primary" or "secondary" character are impossible outside the context of the syndrome analysis.

\section{Space and Time in Luria Neuropsychology}

Another issue that is interesting to discuss when considering space research in Luria neuropsychology is the question of time. In many Humanities and Natural Sciences, the concept of a chronotope has been actively used for many decades - in the words of A. A. Ukhtomsky, determined by the laws of nature connection of space-time coor- 
dinates. Therefore, the question arises: can there be a similar methodological approach in neuropsychological research?

Analysis of neuropsychological data on which brain structures participate in the mental reflection of space and time, how this reflection is disrupted in brain lesions of various localization and lateralization shows us a rather ambiguous picture. It bizarrely combines fairly deep characteristics of the phenomenological manifestations and brain mechanisms of spatial disorders and very fragmentary information about disturbances of certain aspects of temporal perception. To illustrate this statement, just give a few examples. Thus, in the above-mentioned monograph of A. R. Luria Higher Cortical Functions in Man and Their Disturbances in Local Brain Lesions, less than a page is devoted to violations of time perception, and more than 50 pages are devoted to the description of violations of spatial perception (Luria, 1962). He only briefly writes about the existence of chronology and chronognosia; Luria formulates the assumption that chronognosia (sense of time, his immediate perception) is the right hemisphere, and the chronology (the verbal-symbolic level of representations of the time) - left hemisphere. A careful reading of the book gives the impression that time as an independent object of neuropsychological research actually either does not exist, dissolving into other mental processes - speech, memory, movement, conscious regulation, or becomes some variant, a secondary analog of space.

In the works of A.R. Luria and his colleagues, even the determining of time by the clock was considered exclusively as a visual-spatial problem! This approach completely ignores the obvious fact that performing this test requires not only spatial operations, but also the presence of ideas about what exactly the clock measures, the duration of various time periods, the rules of symbolic description of the clock readings, and so on. Another example: logical-grammatical speech expressions that express temporal relations were called quasi-spatial!

The proportion of empirical methods traditionally included in the procedure of complex neuropsychological diagnostics is also disproportionate. As part of a clinical conversation, the subject is asked questions that allow him to assess how time-oriented he is (Luria, 1962); at the end of the survey, he may be asked to estimate the duration of work with the psychologist or the current time without looking at the clock. And that's all about time. Note that the situation regarding the integration of time perception research methods into the procedure of neuropsychological diagnostics has changed only in the last two decades (Balashova \& Kovyazina, 2019). A. R. Luria pays much more attention to space: the description of the methods used to study the spatial components of various mental functions takes up more than a dozen pages in the Higher Cortical Functions (Luria, 1962). This ignoring of time by Russian neuropsychologists, the reasons for which can only be guessed, seems strange and unfounded, because in local brain lesions, various violations of orientation in time, its perception and emotional experience are very common.

What are the reasons for this neglect of time in classical neuropsychological research? There are probably several reasons for this. The first lies in the lack of certainty, the blurring of psychological ideas about time and its neural substrate. The second reason for the priority treatment of neuropsychologists of the Luria era to the study of space, 
apparently, could be due to the fact that many spatial disorders that occur in local brain lesions are well accessible to observation and fixation. They are clearly shown in drawing, writing, constructive activity, movements, perception, and thinking of the patient. Processes, related to the perception and experience of time, occur mainly in the "inner" plane of the mentality, and therefore their study inevitably faces a number of technical and methodological difficulties.

Nevertheless, since the second half of the 80s of the last century, Russian neuropsychologists constantly turn to research on various aspects of time perception. As an example, we can mention the fundamental research of N. N. Bragina and T. A. Dobrokhotova (1988). It was the first time in Russian neuroscience that a comprehensive analysis of human motor, sensory and mental asymmetries was performed. We also studied the features of mental disorders and behavior in different lateral organization of the brain. This analysis allowed us to put forward a hypothesis that the left and right hemispheres take a differentiated part in the formation of a time perspective, in processing information about the past and future of the individual, about the predominant "orientation" of the brain hemispheres to the past or to the future (Bragina \& Dobrokhotova, 1988). The authors also raised the question of the possibility of spatio-temporal description of mentality and consciousness.

As for the cerebral organization of the time factor, neuropsychological concepts are still far from being clearly defined in this area. On the one hand, if we adhere to Lurie's idea of the similarity of space and time, we can assume that the time factor is localized in the same place as the spatial one. However, the idea of a single space-time factor has not yet been confirmed by neuropsychological data (Chomskaya, 2005). On the other hand, a number of modern classifications of neuropsychological factors highlight the factor of successive organization of higher mental functions (i. e., their sequential, smooth deployment in time), which correlates with the work of the premotor zones of the left hemisphere of the brain (Chomskaya, 2005).

Different in nature and severity of violations of orientation in time, time perception, evaluation and measurement of time intervals can be observed in lesions of the right and left hemispheres, various cortical zones, and the median structures of the brain (Bragina \& Dobrokhotova, 1988). Psychophysiological studies demonstrate the activation of complex complexes of cortical zones and subcortical structures (mainly the right hemisphere of the brain) when evaluating the time intervals and duration of their own activity under different semantic settings in healthy subjects (Portnova, Balashova, \& Vartanov, 2006). Thus, over the past decades, neuropsychological studies of the mental reflection of space and time are constantly enriched with new clinical data and new methodological techniques. There is no doubt that the range of studies in which the chronotope category is present in a hidden or explicit way will expand in the future. First of all, because this epistemological category reveals new perspectives of cultural and historical neuropsychology and is a subtle tool for analyzing constantly complicated and changing psychological realities.

Of course, the study of the chronotope in the neuropsychological paradigm is impossible without forming ideas about the brain organization of time perception as a complex, multicomponent mental function. Unfortunately, in the works of A. R. Luria and his 
contemporaries, time, in contrast to space, was studied very little (Balashova, 2015a). The situation began to change only three decades ago. Currently, Russian neuropsychologists are actively investigating the features of time perception at different stages of ontogenesis (in particular, in childhood and in normal and pathological aging), in people with different variants of lateral brain asymmetry. The perception of time, according to many modern psychologists, is a complex functional system. This system includes orientation in the past and current time, the ability to evaluate and measure intervals of various durations, understanding the sequence or simultaneity of events, as well as verbal and figurative representations of time, structuring and experiencing the temporal perspective of the individual as a continuum of the past, present and future. Today, the role of subcortical structures of the brain, frontal and parietal-temporal-occipital zones in providing various components of this complex functional system is actively studied.

\section{Conclusion}

Luria's neuropsychological approach, without a doubt, and today is a lively, rapidly developing science. This also applies to the study of spatial functions. Seeking a deeper and more accurate understanding of the nature of the spatial factor, neuropsychology turns to research of new clinical models (in particular, mental disorders). Neuropsychologists study age-related features of spatial functions, their individual differences due to social and cultural-historical determinants. All these studies will help to clarify the current understanding of the brain mechanisms of spatial functions, their psychological structure and the laws of their formation and functioning at different stages of ontogenesis.

\section{Acknowledgments}

The study was supported by the Russian Foundation for Basic Research, project No. 20-013-00075 "Man in everyday life: Psychological phenomenology and regularities."

\section{References}

Balashova, E. Yu. (2015a). Clinical psychology in search of the meaning of spatial and temporal transformations: Synthesis of research paradigms. Psychological Research, 8(42), 4. Retrieved from http://psystudy.ru/index.php/num/2015v8n42/1165-balashova42.html [In Russian]

Balashova, E. Yu. (2015b). Spatial organization of voluntary movements in normal and pathological aging. Psychological Research, 8(41), 1. Retrieved from http://psystudy.ru/index.php/num/2015v8n41/1133-balashova41.html [In Russian]

Balashova, E. Yu. (2016, July). Neuropsychological assessment of the dysfunction of subcortical structures of the brain in late-age depressions and the possibility of rehabilitation. In G. E. Ivanova, Yu. P. Stakhovskaya \& Yu. P. Zinchenko (Eds.), Selected questions of neurorehabilitation (pp. 27-29). Proceedings of the VIII International Congress "Neurorehabilitation-2016." Moscow: NABI. [In Russian] 
Balashova, E. Yu., \& Kovyazina, M. S. (2019). Neuropsychological diagnostics in questions and answers. Moscow: Genesis. [In Russian]

Balonov, L. Ya., \& Deglin, V. L. (1976). Hearing and speech of the dominant and non-dominant hemispheres. Leningrad: Nauka. [In Russian]

Bekhterev, V. M. (1954). Selected works. Moscow: Medgiz. [In Russian]

Bragina, N. N., \& Dobrokhotova, T. A. (1988). Functional human asymmetries. Moscow: Meditsina. [In Russian]

Buklina, S. B. (2016). Violations of higher mental functions in the defeat of deep and stem structures of the brain. Moscow: Medpress-Inform. [In Russian]

Chomskaya, E. D. (1992). Alexander Romanovich Luria: Scientific biography. Moscow: Military Publishing. [In Russian]

Chomskaya, E. D. (2005). Neuropsychology. St. Petersburg: Peter. [In Russian]

Chomskaya, E. D., Efimova, I. V., Budyka, E. V., \& Enikolopova, E. V. (2011). Neuropsychology of individual differences. Moscow: Akademiya. [In Russian]

Glozman, J. M. (2019). Neuropsychology of childhood. Moscow: Yurayt. [In Russian]

Kiyashchenko, N. K. (1973). Memory impairment in local brain lesions. Moscow: Moscow University Press. [In Russian]

Korchajinskaya, V. I., \& Popova, L. T. (1977). Brain and spatial perception. Moscow: Moscow University Press. [In Russian]

Korsakov, S. S. (1954). Selected works. Moscow: Medgiz. [In Russian]

Korsakova, N. K., Mikadze, Yu. V., \& Balashova, E. Yu. (2017). Failing children: Neuropsychological diagnostics of primary school children. Moscow: Yurayt. [In Russian]

Luria, A. R. (1962). Higher cortical functions in man and their disturbances in local brain lesions. Moscow: Moscow University Press. [In Russian]

Luria, A. R. (1971). Lost and returned world (The story of one injury). Moscow: Moscow University Press. [In Russian]

Luria, A. R. (1973). Basics of neuropsychology. Moscow: Moscow University Press. [In Russian]

Meerson, Ya. A. (1986). Visual agnosia. Leningrad: Nauka. [In Russian]

Mikadze, Yu. V. (2008). Neuropsychology of childhood. St. Petersburg: Peter. [In Russian]

Portnova, G. V., Balashova, E. Yu., \& Vartanov, A. V. (2006). Phenomenon of cognitive capture in evaluating of time intervals. Psychological Journal, 27(1), 67-80. [In Russian]

Simernitskaya, E. G. (1985). Brain and mental processes in ontogenesis. Moscow: Moscow University Press. [In Russian]

Vygotsky, L. S., \& Luria, A. R. (1993). Etudes on the history of behavior: Monkey. Primitive. Child. Moscow: Pedagogika-Press. [In Russian]

Original manuscript received May 05, 2020

Revised manuscript accepted August 01, 2020

First published online November 13, 2020

To cite this article: Balashova, E. Yu. (2020). Space in Luria neuropsychology: Ideas, clinical phenomenology, research methods. Lurian Journal, 1(2), 44-57. doi: 10.15826/Lurian.2020.1.2.4 